\title{
Seasonal variability of the inorganic carbon system in a large coastal plain estuary
}

\author{
Andrew Joesoef ${ }^{1}$, David L. Kirchman ${ }^{2}$, Christopher K. Sommerfield ${ }^{2}$, and Wei-Jun Cai ${ }^{1}$ \\ ${ }^{1}$ School of Marine Science and Policy, University of Delaware, Newark, DE 19716, USA \\ ${ }^{2}$ School of Marine Science and Policy, University of Delaware, Lewes, DE 19958, USA \\ Correspondence to: Wei-Jun Cai (wcai@udel.edu)
}

Received: 6 June 2017 - Discussion started: 9 June 2017

Revised: 18 September 2017 - Accepted: 19 September 2017 - Published: 8 November 2017

\begin{abstract}
Carbonate geochemistry research in large estuarine systems is limited. More work is needed to understand how changes in land-use activity influence watershed export of organic and inorganic carbon, acids, and nutrients to the coastal ocean. To investigate the seasonal variation of the inorganic carbon system in the Delaware Estuary, one of the largest estuaries along the US east coast, dissolved inorganic carbon (DIC), total alkalinity (TA), and $\mathrm{pH}$ were measured along the estuary from June 2013 to April 2015. In addition, DIC, TA, and $\mathrm{pH}$ were periodically measured from March to October 2015 in the nontidal freshwater Delaware, Schuylkill, and Christina rivers over a range of discharge conditions. There were strong negative relationships between river TA and discharge, suggesting that changes in $\mathrm{HCO}_{3}^{-}$ concentrations reflect dilution of weathering products in the drainage basin. The ratio of DIC to TA, an understudied but important property, was high (1.11) during high discharge and low (0.94) during low discharge, reflecting additional DIC input in the form of carbon dioxide $\left(\mathrm{CO}_{2}\right)$, most likely from terrestrial organic matter decomposition, rather than bicarbonate $\left(\mathrm{HCO}_{3}^{-}\right)$inputs due to drainage basin weathering processes. This is also a result of $\mathrm{CO}_{2}$ loss to the atmosphere due to rapid water transit during the wet season. Our data further show that elevated DIC in the Schuylkill River is substantially different than that in the Delaware River. Thus, tributary contributions must be considered when attributing estuarine DIC sources to the internal carbon cycle versus external processes such as drainage basin mineralogy, weathering intensity, and discharge patterns. Longterm records in the Delaware and Schuylkill rivers indicate shifts toward higher alkalinity in estuarine waters over time, as has been found in other estuaries worldwide. Annual
\end{abstract}

DIC input flux to the estuary and export flux to the coastal ocean are estimated to be $15.7 \pm 8.2 \times 10^{9} \mathrm{molC} \mathrm{yr}^{-1}$ and $16.5 \pm 10.6 \times 10^{9} \mathrm{molC} \mathrm{yr}^{-1}$, respectively, while net DIC production within the estuary including inputs from intertidal

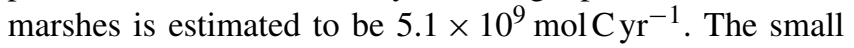
difference between riverine input and export flux suggests that, in the case of the Delaware Estuary and perhaps other large coastal systems with long freshwater residence times, the majority of the DIC produced in the estuary by biological processes is exchanged with the atmosphere rather than exported to the sea.

\section{Introduction}

The global carbon cycle involves dynamical processes of carbon exchange among the earth's atmosphere, land, vegetation, coastal zones, and oceans. Over the past century, human perturbations and land-use changes have significantly modified the transport of carbon across the land-to-ocean continuum and have resulted in imbalances to present-day carbon fluxes and storage reservoirs (Aumont et al., 2001; Cotrim da Cunha et al., 2007; Quinton et al., 2010; Bauer et al., 2013; Regnier et al., 2013). Most carbon fluxes in inland waters involve inputs from soil-derived carbon, chemical weathering of carbonate and silicate minerals, wetlands, dissolved carbon in sewage waste, and organic carbon produced by phytoplankton in surface waters (Battin et al., 2009; Tranvik et al., 2009; Regnier et al., 2013; Abril et al., 2014). To balance the influx of carbon, a large fraction is returned to the atmosphere by organic carbon decomposition within inland waters, transported to adjacent waters, buried in freshwater 
sediments, and in some cases released as methane $\left(\mathrm{CH}_{4}\right)$ gas (Downing et al., 2008; Bastviken et al., 2011).

Total alkalinity (TA) is defined as $\mathrm{TA}=\left[\mathrm{HCO}_{3}^{-}\right]+2\left[\mathrm{CO}_{3}^{2-}\right]$ plus all other weak bases that can accept $\mathrm{H}^{+}$when titrated to the carbonic acid endpoint. Comparably, dissolved inorganic carbon (DIC) is expressed as the sum of all inorganic carbon species $\left(\left[\mathrm{CO}_{2}\right],\left[\mathrm{HCO}_{3}^{-}\right],\left[\mathrm{CO}_{3}^{2-}\right]\right)$. In terrestrial aquatic systems, there are three sources of dissolved inorganic carbon. The most important sources are from the carbonate and silicate weathering processes as described below.

$$
\begin{aligned}
& \mathrm{CaCO}_{3}+\mathrm{CO}_{2} \rightarrow 2 \mathrm{HCO}_{3}^{-}+\mathrm{Ca}^{2+} \\
& \mathrm{CaSiO}_{3}+2 \mathrm{CO}_{2}+3 \mathrm{H}_{2} \mathrm{O} \rightarrow 2 \mathrm{HCO}_{3}^{-}+\mathrm{Ca}^{2+}+\mathrm{H}_{4} \mathrm{SiO}_{4}
\end{aligned}
$$

In both cases, the amounts of DIC and TA production are equal. Here, $\mathrm{CO}_{2}$ may come from soil organic matter respiration but ultimately it is linked to the atmospheric $\mathrm{CO}_{2}$. Respiration of soil and aquatic organic carbon is another source of $\mathrm{CO}_{2}$, but it does not contribute to TA. Since alkalinity of natural waters is mainly composed of $\left[\mathrm{HCO}_{3}^{-}\right]$ and $\left[\mathrm{CO}_{3}^{2-}\right]$, DIC-to-TA ratios can provide broad insight into the sources of carbon, aquatic $\mathrm{pH}$ dynamics and regional carbonate buffering capacity. Large shifts in seasonal precipitation and weathering rates can significantly affect DIC and TA concentrations (Probst et al., 1992; Cai, 2003; Guo et al., 2008).

Typically, the supply of inorganic carbon by rivers to the coastal ocean is governed by river discharge, weathering intensity, and the geology of the drainage basin (White and Blum, 1995; White, 2003; Guo et al., 2008). The weathering of carbonate and silicate minerals consumes atmospheric $\mathrm{CO}_{2}$ and transports $\mathrm{HCO}_{3}^{-}$ions and subsequent cation and anion products into oceanic systems. Eventually, $\mathrm{CO}_{2}$ is released back into the atmosphere via oceanic carbonate sedimentation and volcanic activity (Lerman et al., 2004; Regnier et al., 2013). Guo et al. (2008) found that, in the Pearl River estuary, DIC and TA values were substantially lower during the wet season $\left(\sim 1000\right.$ and $700 \mu \mathrm{mol} \mathrm{kg}^{-1}$, respectively $)$ than during the dry season $\left(>2700\right.$ and $>2400 \mu \mathrm{mol} \mathrm{kg}{ }^{-1}$, respectively). They suggested that the much lower DIC and TA values in the wet season were a result of increased river discharge diluting overall production of DIC and TA by weathering and decomposition. Similar results were found in the Mississippi and Changjiang where river $\mathrm{HCO}_{3}^{-}$concentration and discharge are negatively correlated (Cai, 2003; Cai et al., 2008).

As carbon is transported horizontally along the land and ocean continuum, various environmental processes impact the total carbon fluxes between reservoirs. Recent synthesis suggests that a variable but relatively small fraction of $\mathrm{CO}_{2}$ emitted in estuaries is sustained by freshwater inputs while most of the $\mathrm{CO}_{2}$ released is from local net heterotrophy, with the majority of organic carbon inputs stemming from adjacent salt marsh and mangrove ecosystems (Cai,
2011; Regnier et al., 2013). These systems are supported by inputs from various autochthonous and allochthonous organic carbon sources, $\mathrm{CO}_{2}$ enriched sediment intertidal waters during ebbing, and high concentrations of dissolved inorganic carbon from intertidal and subtidal benthic communities (Cai et al., 2003; Neubauer and Anderson, 2003; Wang and Cai, 2004; Ferrón et al., 2007; Chen and Borges, 2009). Terrestrial organic carbon that is transported by large and fast-transit river systems generally bypasses decomposition in estuaries and contributes to respiration along coastal ocean margins (Cai, 2011). Consequently, rapid increases in atmospheric $\mathrm{CO}_{2}$ concentrations may have reduced the amount of $\mathrm{CO}_{2}$ released along ocean margin systems, especially in low-latitude zones where a majority of the terrestrial organic carbon is delivered (Cai, 2011).

While there have been several inorganic carbon studies on rapidly transiting large river systems, globally carbonate chemistry research in large estuaries remains limited (Ternon et al., 2000; Cai, 2003; Cai et al., 2004, 2008; Cooley et al., 2007; Liu et al., 2014). Further, the majority of past estuarine $\mathrm{CO}_{2}$ studies have focused primarily on small estuarine systems (typically within 1-100 km in length and less than $10 \mathrm{~m}$ in depth) with rapid water transit and short freshwater residence times $\left(10^{-3}\right.$ to $10^{-1}$ years) (Chen and Borges, 2009; Cai, 2011; Borges and Abril, 2011; Dürr et al., 2011). Thus, there is a lack of carbonate research in large estuaries with long water residence times. In this study, we investigated the carbonate geochemistry of the Delaware, Schuylkill, and Christina rivers, the three main tributaries of the Delaware Estuary, which is one of the largest estuaries along the US east coast. Using monthly sampling in 2013-2015, we examined how input from multiple tributaries, contrasting geographical settings, and physical mixing processes affect total riverine DIC and TA fluxes, internal net ecosystem production, and overall export flux in a large coastal plain estuary. Using historical and contemporary data collected along the Delaware and Schuylkill rivers, we further explored how tributaries influence regional trends in riverine carbonate chemistry.

\section{Methods}

\subsection{Study area}

The Delaware Estuary is a $215 \mathrm{~km}$ long coastal plain estuary that extends from the head of the tidal Delaware River at Trenton, New Jersey, to the mouth of the Delaware Bay between Cape Henlopen and Cape May (Fig. 1). The Delaware River provides $50-60 \%$ of the total freshwater inflow to the estuary. Based on US Geological Survey (USGS) stream gauging data, the annual mean discharge of the Delaware River at Trenton is $340 \mathrm{~m}^{3} \mathrm{~s}^{-1}(1950-2015)$. Of the many small rivers in New Jersey, Pennsylvania, and Delaware that flow into the estuary, the Schuylkill River is the largest with 


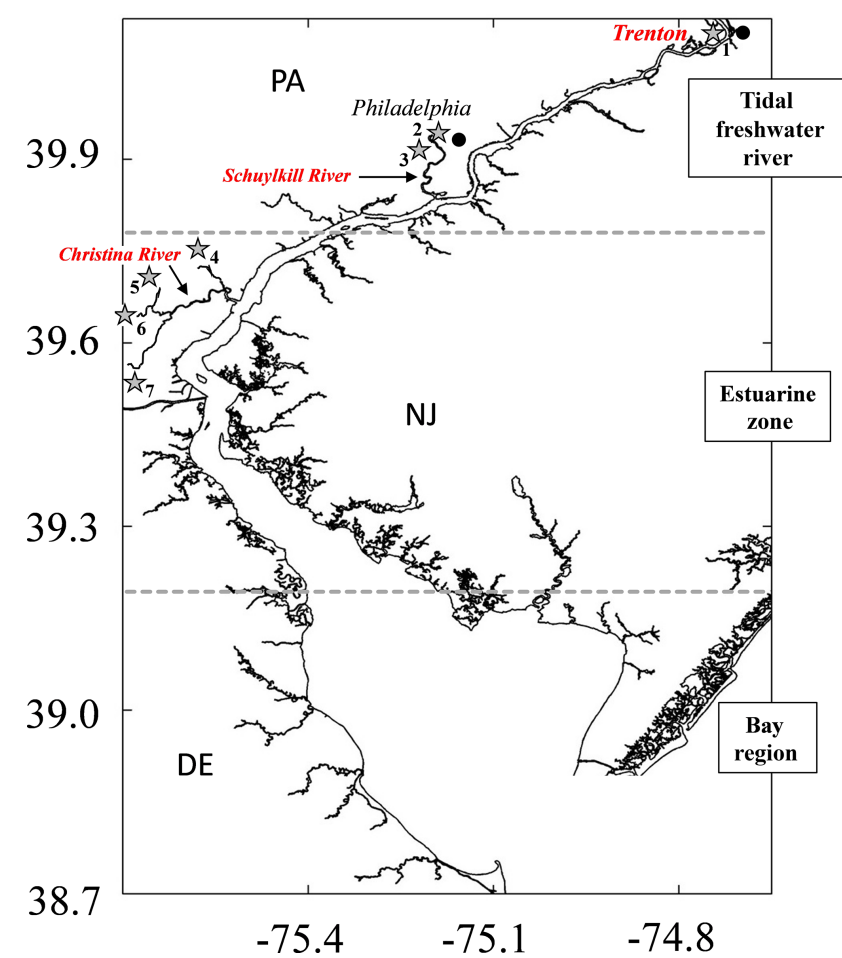

Figure 1. Map of the Delaware Estuary and river tributaries. Gray stars indicate USGS gauging stations (1) 01463500, (2) 01474010, (3) 01474500, (4) 01481500, (5) 01480015, (6) 01479000, and (7) 01478000 .

an annual mean discharge of $80 \mathrm{~m}^{3} \mathrm{~s}^{-1}$, whereas the Brandywine and Christina rivers are the smallest gauged tributaries with a combined mean of $20 \mathrm{~m}^{3} \mathrm{~s}^{-1}$. Together, the Delaware, Schuylkill, Brandywine, and Christina rivers contribute $70 \%$ of the total freshwater input to the estuary with the balance sourced mostly by smaller ungauged rivers (Sutton et al., 1996). Freshwater input from municipal wastewater treatment plants is important as well with a discharge around $30 \mathrm{~m}^{3} \mathrm{~s}^{-1}$. As the tidal freshwater river passes through the industrial Philadelphia region, it transitions to an extensive estuary and bay system surrounded by intertidal salt marshes. Depending on precipitation and discharge, freshwater residence times in the Delaware Estuary generally range from 40 to 90 days but may exceed 200 days during periods of drought. Circulation in the estuary is influenced by tides, wind, and dynamical interactions between freshwater runoff from the drainage basin and saltwater inflow from the Atlantic Ocean (Wong and Sommerfield, 2009; Sommerfield and Wong, 2011; Aristizábal and Chant, 2015).

\subsection{Field measurements}

DIC, TA, and $\mathrm{pH}$ were measured along the salinity gradient of the Delaware Estuary on eight cruises: 8-10 June 2013, 17-22 November 2013, 23-24 March 2014, 2-3 July 2014, 27 August to 1 September 2014, 30 October to 2 Novem-
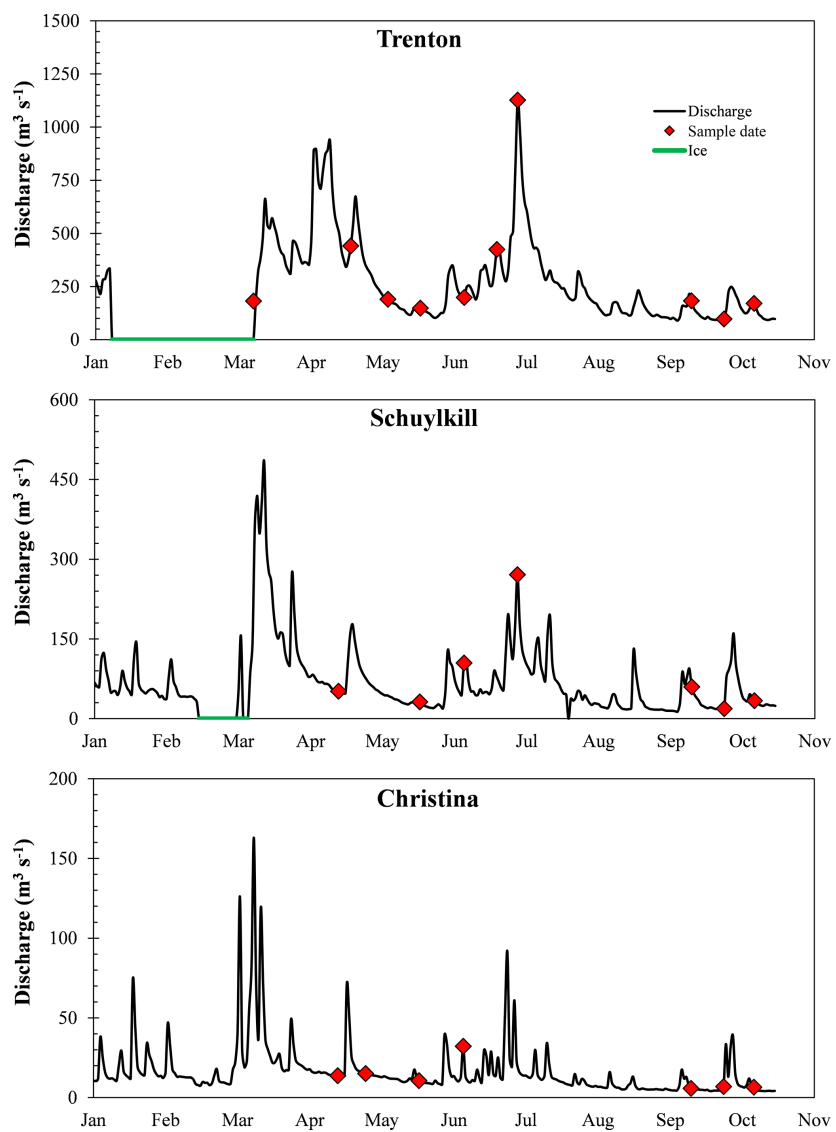

Figure 2. Daily discharge at the Delaware (Trenton), Schuylkill, and Christina rivers from March to October 2015. Note the different scales used for each river. Red diamonds indicate exact sampling dates. Green lines are when river waters were frozen.

ber 2014, 5 December 2014, and 6 April 2015. Stations varied from cruise to cruise. Water column samples were collected with a SBE 911plus CTD rosette system (SeaBird Electronics). Discrete underway samples were taken from the outlet of an onboard SeaBird thermosalinograph (SBE45), which measured underway surface water temperature and salinity. In addition to the eight cruises, DIC, TA, and $\mathrm{pH}$ were periodically collected from March to October 2015 from the Delaware, Schuylkill, and Christina rivers (Figs. 1 and 2; Table 1). Instantaneous water discharge data for the Delaware and Schuylkill rivers were available from gauging stations in Trenton, NJ, and Philadelphia, PA (USGS gauges 01463500 and 01474500 , respectively) (Fig. 2). Discharge data for the Christina River, Brandywine Creek, Red Clay Creek, and White Clay Creek were used to compute total freshwater discharge for the Christina River system (USGS gauges 01478000, 01481500, 01480015, and 01479000). 
Table 1. Sampling dates, average discharge, $\mathrm{pH}$, DIC, TA, and DIC-to-TA ratio in the Delaware (Trenton), Schuylkill, and Christina rivers.

\begin{tabular}{llrrrrr}
\hline Location & Date & $\begin{array}{r}\text { Discharge } \\
\left(\mathrm{m}^{3} \mathrm{~s}^{-1}\right)\end{array}$ & $\begin{array}{r}\mathrm{pH} \\
\left(\text { at } 25^{\circ} \mathrm{C}\right)\end{array}$ & $\begin{array}{r}\mathrm{DIC} \\
\left(\mu \mathrm{mol} \mathrm{kg}{ }^{-1}\right)\end{array}$ & $\begin{array}{r}\text { TA } \\
\left.(\mu \mathrm{mol} \mathrm{kg})^{-1}\right)\end{array}$ & DIC: TA \\
\hline \multirow{2}{*}{ Trenton } & 10 Mar 2015 & 182 & 8.8 & 973.4 & 1038.8 & 0.94 \\
& 21 Apr 2015 & 442 & 7.8 & 745.2 & 723.7 & 1.03 \\
& 7 May 2015 & 190 & 8.8 & 856.5 & 902.9 & 0.95 \\
& 21 May 2015 & 148 & 8.0 & 1025.5 & 1015.9 & 1.01 \\
& 9 Jun 2015 & 199 & 8.2 & 857.8 & 869.2 & 0.99 \\
& 23 Jun 2015 & 425 & 7.7 & 783.5 & 765.5 & 1.02 \\
& 2 Jul 2015 & 1127 & 7.2 & 454.2 & 410.4 & 1.11 \\
& 15 Sep 2015 & 183 & 8.2 & 945.8 & 936.7 & 1.01 \\
& 29 Sep 2015 & 98 & 8.7 & 945.8 & 1103.9 & 0.86 \\
& 12 Oct 2015 & 170 & 8.1 & 1095.2 & 1046.1 & 1.05 \\
\hline \multirow{2}{*}{ Schuylkill } & 16 Apr 2015 & 52 & 8.9 & 1421.2 & 1525.7 & 0.93 \\
& 21 May 2015 & 32 & 8.1 & 1682.9 & 1655.9 & 1.02 \\
& 9 Jun 2015 & 105 & 7.9 & 1400.1 & 1371.3 & 1.02 \\
& 2 Jul 2015 & 271 & 7.7 & 1095.3 & 1026.3 & 1.07 \\
& 15 Sep 2015 & 60 & 7.8 & 1506.1 & 1472.2 & 1.02 \\
& 29 Sep 2015 & 19 & 8.1 & 2071.3 & 2107.8 & 0.98 \\
& 12 Oct 2015 & 34 & 8.3 & 1869.3 & 1851.4 & 1.01 \\
\hline Christina & 16 Apr 2015 & 14 & 7.7 & 1056.5 & 1015.1 & 1.04 \\
& 28 Apr 2015 & 15 & 7.5 & 1076.4 & 1018.6 & 1.06 \\
& 21 May 2015 & 11 & 7.7 & 1134.1 & 1072.8 & 1.06 \\
& 9 Jun 2015 & 32 & 7.5 & 1089.4 & 1004.0 & 1.08 \\
& 15 Sep 2015 & 6 & 7.9 & 1326.9 & 1210.6 & 1.10 \\
& 29 Sep 2015 & 7 & 8.0 & 1188.6 & 1165.4 & 1.02 \\
& 12 Oct 2015 & 7 & 8.0 & 1199.6 & 1168.0 & 1.03 \\
\hline
\end{tabular}

\subsection{Analytical methods}

DIC and TA samples were filtered through a cellulose acetate filter $(0.45 \mu \mathrm{m})$ into $250 \mathrm{~mL}$ borosilicate bottles, fixed with $100 \mu \mathrm{L}$ of saturated mercury bichloride solution, preserved at $4^{\circ} \mathrm{C}$, and analyzed within 2 weeks of sample collection (Cai and Wang, 1998; Jiang et al., 2008). DIC was determined via acid extraction by quantifying the released $\mathrm{CO}_{2}$ using an infrared gas analyzer (AS-C3, Apollo SciTech). TA was measured by Gran titration (Gran, 1952) using an open-cell semiautomatic titration system (AS-ALK2, Apollo SciTech) (Cai et al., 2010; Huang et al., 2012). Accepted analytical precision based on three repeats was $\pm 2 \mu \mathrm{mol} \mathrm{kg}{ }^{-1}$, and all measurements were calibrated against certified reference material (provided by A. G. Dickson from Scripps Institution of Oceanography) (Huang et al., 2012). For pH measurements, water samples were collected in glass bottles with a narrow mouth and left in a thermal bath (at $25^{\circ}$ ) for about 30-60 min. The $\mathrm{pH}$ was then determined onboard using an Orion 3-Star Plus pH Benchtop Meter with a Ross $\mathrm{pH}$ electrode (Thermo Fisher Scientific Inc., Beverly, MA, USA) and calibrated using three National Bureau Standard (NBS) pH buffers of 4.01, 7.00, and 10.01. Note that the narrow mouth of the glass bottle is only slightly larger than the outer diameter of the $\mathrm{pH}$ electrode, thus preventing $\mathrm{CO}_{2}$ degassing during the analysis. While the analytical precision is \pm 0.005 units, the expected accuracy is probably not better than $\pm 0.01 \mathrm{pH}$ units.

\section{Results}

\subsection{Spatial distributions of DIC and TA}

DIC and TA varied greatly in the estuary and with season (975-2015 and 915-2225 $\mu \mathrm{mol} \mathrm{kg}{ }^{-1}$, respectively) (Fig. 3). DIC and TA were lowest near zero salinity in the spring and summer when river discharge was strong and were highest in the fall and winter when discharge was weak (Fig. 3). At the bay mouth $(S>30)$, DIC and TA concentrations remained fairly constant throughout all seasons (1920-1990 and $2095-2180 \mu \mathrm{mol} \mathrm{kg}^{-1}$, respectively). During spring and summer, DIC was reduced while $\mathrm{pH}(8.0-8.5)$ was highest in waters with salinity values of $15-25$, suggesting biological consumption of $\mathrm{CO}_{2}$ in the mid- to lower bay (Fig. 3). In the fall and winter, DIC and TA generally varied linearly in relation to salinity, although the change in $\mathrm{pH}$ was small across the salinity gradient (Fig. 3). At salinity $<2.5$, $\mathrm{pH}$ decreased greatly, reaching as low as 7.1 in June.

Depending on river discharge conditions, DIC concentrations typically range from about 300 to $1200 \mu \mathrm{mol} \mathrm{kg}-1$ 

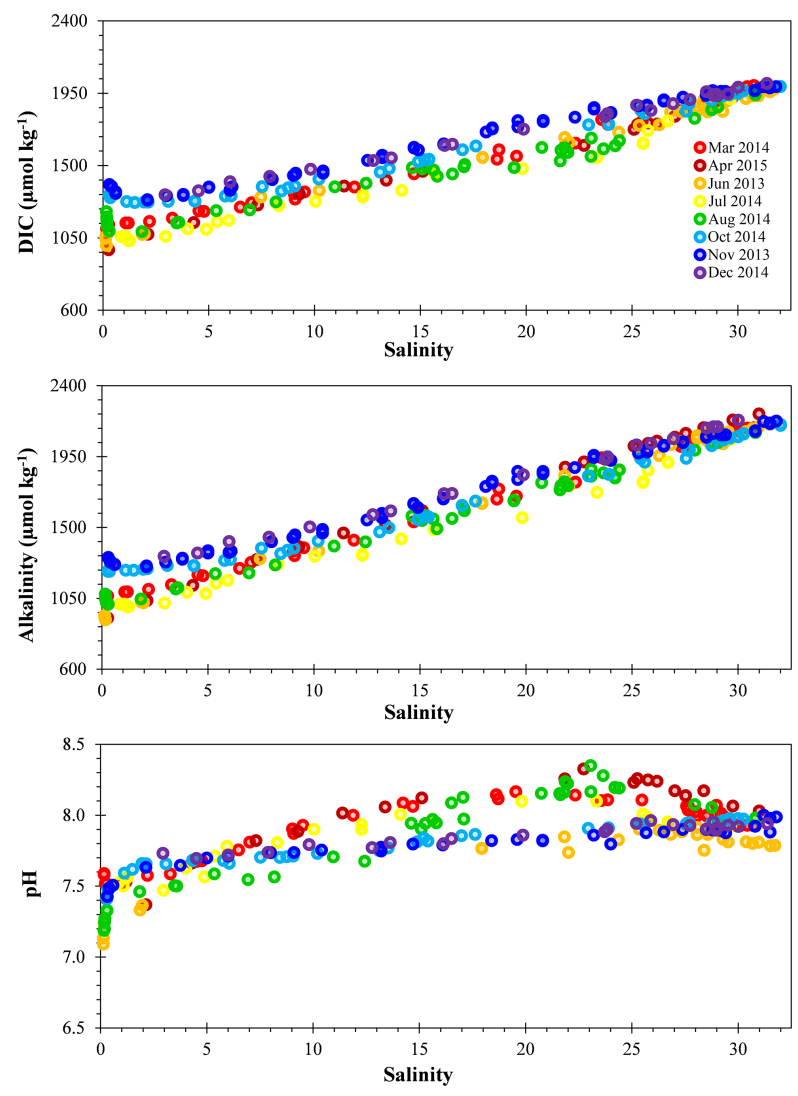

Figure 3. Salinity distributions of DIC, alkalinity, and $\mathrm{pH}$ in the Delaware Estuary.

at the head of the estuary at Trenton (Sharp et al., 2009). During the spring and summer surveys when discharge was high, DIC and TA concentrations were about $300 \mu \mathrm{mol} \mathrm{kg}-1$ lower than concentrations in the fall when river discharge was low (Fig. 3). Following a 5-day high-discharge event, TA on 2 July 2015 was $410.4 \mu \mathrm{mol} \mathrm{kg}^{-1}$ (Table 1), about $600 \mu \mathrm{mol} \mathrm{kg}^{-1}$ lower than the high TA in the river at low discharge from March to October (Table 1). DIC followed similar patterns. TA also changed greatly at the Schuylkill River. Additionally, when average river discharge in the Schuylkill River was less than $50 \mathrm{~m}^{3} \mathrm{~s}^{-1}$, TA values exceeded $1500 \mu \mathrm{mol} \mathrm{kg}^{-1}$ (Table 1).

While TA in the Schuylkill River was nearly double that of the Delaware River at Trenton, Delaware River discharge was nearly 4 times greater than the Schuylkill River discharge (Table 1). Moreover, the average discharge in the Delaware River was more than 10 times greater than discharge of the Christina River (Table 1). Despite mixing from multiple sources, based on the relative discharges of the tributaries, the average riverine TA is predominantly governed by carbonate concentrations in the Delaware River. However, during periods of low discharge, TA increased significantly at the Schuylkill River (Fig. 4 and Table 1). On 29 September 2015, TA values were as high as the oceanic values at the bay mouth, exceeding $2100 \mu \mathrm{mol} \mathrm{kg}{ }^{-1}$. The mixing of high TA from the Schuylkill River may have increased TA values at the confluence of the Delaware and Schuylkill River. Slight increases in TA values were observed at the northernmost points (around 125-150 km upstream) of the August 2014, November 2013, and October 2014 cruises (Fig. 5).

\subsection{DIC and TA riverine flux}

We examined inputs of DIC and TA from the Delaware, Schuylkill, and Christina rivers from March to October 2015 (Fig. 2). As DIC and TA in the Delaware River and tributaries were only measured periodically, in order to estimate input fluxes precisely we first established a quantitative relationship between concentration and river discharge (Cai et al., 2008). We found that the observed DIC and TA concentrations in each tributary varied negatively with river discharge (Fig. 4). These relationships were used to estimate DIC and TA in the tributaries from average discharge measured for each cruise (Table 2), which were then combined with daily discharges recorded at each river from 2013 to 2015 to compute a more robust estimate. Using this approach, we estimate that the annual flux of DIC and TA from the three rivers to the estuary was $11.0 \pm 5.8 \times 10^{9}$ and $10.8 \pm 5.1 \times 10^{9} \mathrm{molC} \mathrm{yr}^{-1}$, respectively.

\subsection{DIC and TA export flux}

DIC and TA values varied linearly with salinity near the ocean end-member value, suggesting no net addition or removal of DIC and TA. The effective river end-member concentrations of DIC and TA were calculated by extrapolating the DIC and TA conservative mixing lines from the highsalinity waters to zero salinity (Fig. 3) (Cai et al., 2004; Guo et al., 2008). The difference between the effective and actual concentrations at the river end-member indicates the amount of DIC and TA added or removed during mixing and therefore not transported to the ocean (Boyle et al., 1974; Cai and Wang, 1998; Liu et al., 2014). Using the effective concentrations and the combined river discharge for the Delaware, Schuylkill, and Christina rivers recorded over the entire cruise period, including discharges recorded 10 days prior to the survey, annual DIC and TA fluxes to the ocean were estimated to be $11.5 \pm 7.4 \times 10^{9}$ and $13.0 \pm 9.0 \times 10^{9} \mathrm{molC} \mathrm{yr}^{-1}$ (Table 3). Thus, DIC export flux out of the estuary is only $4.5 \%$ greater than the riverine flux into the estuary. However, TA flux increased $20 \%$ throughout the estuarine zone.

\section{Discussion}

\subsection{Influence of river discharge and weathering intensity}

The extensive and routine collection of water samples conducted by USGS allows us to explore long-term trends in 

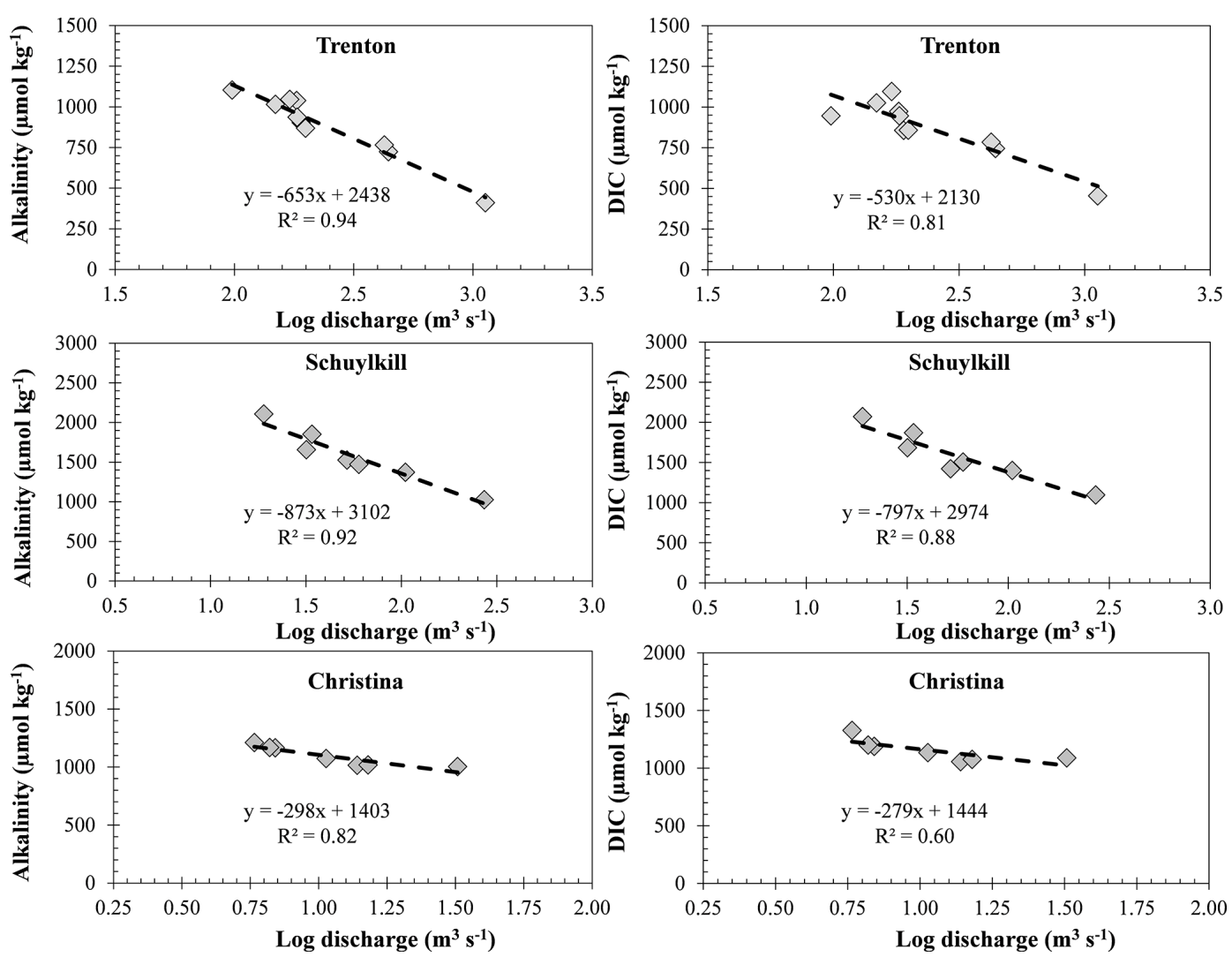

Figure 4. Alkalinity and DIC versus log discharge at the Delaware (Trenton), Schuylkill, and Christina rivers. Note the different scales used for each river.

Table 2. Estimated TA and DIC in the Delaware (Trenton), Schuylkill, and Christina rivers, calculated by linear regression using discharge and their input fluxes to the Delaware Estuary.

\begin{tabular}{|c|c|c|c|c|c|c|c|c|}
\hline \multirow[t]{2}{*}{ Survey } & \multicolumn{2}{|c|}{ Trenton } & \multicolumn{2}{|c|}{ Schuylkill } & \multicolumn{2}{|c|}{ Christina } & \multirow{2}{*}{$\begin{array}{r}\text { TA } \\
\text { input flux } \\
\left(10^{9} \mathrm{~mol} \mathrm{yr}^{-1}\right)\end{array}$} & \multirow{2}{*}{$\begin{array}{r}\text { DIC } \\
\text { input flux } \\
\left(10^{9} \mathrm{~mol} \mathrm{yr}^{-1}\right)\end{array}$} \\
\hline & $\begin{array}{r}\mathrm{TA} \\
\left(\mu \mathrm{mol} \mathrm{kg}{ }^{-1}\right)\end{array}$ & $\begin{array}{r}\text { DIC } \\
\left(\mu \mathrm{mol} \mathrm{kg}{ }^{-1}\right)\end{array}$ & $\begin{array}{r}\text { TA } \\
\left(\mu \mathrm{molkg}^{-1}\right)\end{array}$ & $\begin{array}{r}\text { DIC } \\
\left(\mu \mathrm{mol} \mathrm{kg}{ }^{-1}\right)\end{array}$ & $\begin{array}{r}\text { TA } \\
\left(\mu \mathrm{mol} \mathrm{kg}{ }^{-1}\right)\end{array}$ & $\begin{array}{r}\text { DIC } \\
\left(\mu \mathrm{mol} \mathrm{kg}{ }^{-1}\right)\end{array}$ & & \\
\hline March 2014 & 700.3 & 721.5 & 1341.8 & 1366.8 & 935.3 & 1004.8 & 15.6 & 16.0 \\
\hline April 2015 & 609.1 & 647.6 & 1382.8 & 1404.3 & 1030.1 & 1093.7 & 16.7 & 17.6 \\
\hline June 2013 & 634.0 & 667.8 & 995.4 & 1050.5 & 870.7 & 944.2 & 21.3 & 22.5 \\
\hline July 2014 & 901.6 & 884.7 & 1565.3 & 1571.0 & 1050.7 & 1113.0 & 9.7 & 9.6 \\
\hline August 2014 & 1101.0 & 1046.4 & 1977.9 & 1947.8 & 1131.8 & 1188.9 & 5.4 & 5.2 \\
\hline October 2014 & 1147.2 & 1083.9 & 1860.7 & 1840.8 & 1123.1 & 1180.8 & 5.3 & 5.1 \\
\hline November 2013 & 1154.0 & 1089.4 & 1929.7 & 1903.7 & 1112.0 & 1170.3 & 5.0 & 4.8 \\
\hline December 2014 & 998.9 & 963.7 & 1548.0 & 1555.1 & 1057.9 & 1119.7 & 8.4 & 8.3 \\
\hline Annual average & 894.6 & 879.1 & 1568.2 & 1573.6 & 1044.4 & 1107.0 & 10.8 & 11.0 \\
\hline
\end{tabular}

alkalinity (from the mid-20th to early 21 st century) in the Delaware and Schuylkill rivers (USGS stations 01463500 and 01474500 , respectively). For USGS alkalinity values, we use similar approaches to those conducted in Stets et al. (2014). We combine eight various parameter codes that include alkalinity, acid neutralizing capacity (ANC), or $\mathrm{HCO}_{3}^{-}$ (Table 4). Alkalinity and ANC follow identical electrometric procedures except that alkalinity samples are filtered while ANC samples are not. The compilation of historical USGS water quality data from 1940 to the present shows that TA for the Delaware River at Trenton was negatively correlated with river discharge (Fig. 6). TA was highest during low flow season (fall) and lowest during high flow season (spring) (Fig. 6). Negative correlation between TA and river discharge has been observed for other river systems such as the Mississippi, Changjiang, Pearl, Huanghe, Congo, and Indus (Probst et al., 1992; Karim and Veizer, 2000; Cai, 2003; Li and Zhang, 2003; Chen et al., 2008; Guo et al., 2008; Liu et al., 
Table 3. Effective TA and DIC as a function of salinity, calculated by linear regression using data from high-salinity waters in the Delaware Estuary and their export fluxes to the ocean.

\begin{tabular}{|c|c|c|c|c|c|c|c|c|c|}
\hline \multirow[t]{2}{*}{ Survey } & \multicolumn{3}{|c|}{$\begin{array}{l}\text { Effective TA } \\
\left(\mu \mathrm{molkg}{ }^{-1}\right)\end{array}$} & \multicolumn{3}{|c|}{$\begin{array}{c}\text { Effective DIC } \\
\left(\mu \mathrm{mol} \mathrm{kg}{ }^{-1}\right)\end{array}$} & \multirow{2}{*}{$\begin{array}{r}\text { Total } \\
\text { discharge } \\
\left(\mathrm{m}^{3} \mathrm{~s}^{-1}\right)\end{array}$} & \multirow{2}{*}{$\begin{array}{r}\mathrm{TA} \\
\text { export flux } \\
\left(10^{9} \mathrm{~mol} \mathrm{yr}^{-1}\right)\end{array}$} & \multirow{2}{*}{$\begin{array}{r}\text { DIC } \\
\text { export flux } \\
\left(10^{9} \mathrm{~mol} \mathrm{yr}^{-1}\right)\end{array}$} \\
\hline & Slope & Intercept & $R^{2}$ & Slope & Intercept & $R^{2}$ & & & \\
\hline Mar 2014 & 35.99 & 1034 & 0.97 & 35.59 & 889 & 0.97 & 597 & 19.5 & 16.7 \\
\hline Apr 2015 & 37.33 & 1071 & 0.99 & 40.73 & 714 & 0.99 & 740 & 25.0 & 16.7 \\
\hline Jun 2013 & 37.91 & 978 & 0.93 & 32.03 & 948 & 0.94 & 895 & 27.6 & 26.8 \\
\hline Jul 2014 & 51.05 & 532 & 0.96 & 46.21 & 514 & 0.90 & 297 & 5.0 & 4.8 \\
\hline Aug 2014 & 36.63 & 974 & 0.97 & 37.99 & 747 & 0.94 & 139 & 4.3 & 3.3 \\
\hline Oct 2014 & 37.45 & 954 & 0.98 & 28.69 & 1087 & 0.97 & 129 & 3.9 & 4.4 \\
\hline Nov 2013 & 28.48 & 1261 & 0.99 & 20.27 & 1360 & 0.98 & 124 & 4.9 & 5.3 \\
\hline Dec 2014 & 35.28 & 1119 & 0.99 & 25.16 & 1219 & 0.96 & 234 & 8.3 & 9.0 \\
\hline Annual average & & & & & & & 387 & 13.0 & 11.5 \\
\hline
\end{tabular}

Table 4. USGS parameter codes used during analysis.

\begin{tabular}{llrr}
\hline $\begin{array}{l}\text { Parameter } \\
\text { code }\end{array}$ & Parameter description & $\begin{array}{r}\text { Total } \\
\text { count }\end{array}$ & $\begin{array}{r}\text { Percentage of } \\
\text { total count }\end{array}$ \\
\hline 00410 & Acid neutralizing capacity, water, unfiltered, fixed endpoint titration, field & 920 & 28.5 \\
00419 & Acid neutralizing capacity, water, unfiltered, inflection-point titration, field & 25 & 0.8 \\
00440 & Bicarbonate, water, unfiltered, fixed endpoint titration, field & 1529 & 47.4 \\
00450 & Bicarbonate, water, unfiltered, inflection-point titration, field & 25 & 0.8 \\
00453 & Bicarbonate, water, filtered, inflection-point titration, field & 133 & 2.7 \\
29801 & Alkalinity, water, filtered, fixed endpoint titration, laboratory & 283 & 4.1 \\
39086 & Alkalinity, water, filtered, inflection-point titration, field & 8.8 \\
90410 & Acid neutralizing capacity, water, unfiltered, fixed endpoint titration, laboratory & 224 & 6.9 \\
\hline
\end{tabular}

2014). In the Delaware River, the highest TA fluxes occurred during peak flow season (spring) and the lowest TA fluxes occurred during the lowest flow season (fall) (Fig. 6). It is important to note that flux is governed by both river discharge and concentration. In the case of an extreme weather event, TA fluxes may be twice as large as the average flux. Under the same conditions, if river discharge is 4 times higher, concentrations must be reduced in half to yield a twofold increase in TA flux. Thus, it appears that variation in TA (and DIC) is mainly a result of seasonal shifts in river discharge. Such fluctuations in river DIC and TA are expected as they are primarily governed by the dilution of weathering products by rain, and also are compensated by the increased weathering flux and other sources during wet seasons (White and Blum, 1995; White, 2003; Cai et al., 2008).

Another interesting but rarely reported phenomenon is the seasonal variation of the DIC-to-TA ratio at the freshwater end-members. At Trenton, the ratios (1.02-1.11) were highest during high discharge periods $\left(>200 \mathrm{~m}^{3} \mathrm{~s}^{-1}\right)$ and lowest $(0.86-1.01)$ at low discharge periods $\left(<150 \mathrm{~m}^{3} \mathrm{~s}^{-1}\right)$ (Table 1). Similar results were found in the Schuylkill River where DIC-to-TA ratios were highest (1.02-1.07) at high discharge $\left(>100 \mathrm{~m}^{3} \mathrm{~s}^{-1}\right)$ and lowest (0.93 to 1.02$)$ during low discharge $\left(<75 \mathrm{~m}^{3} \mathrm{~s}^{-1}\right)$ (Table 1$)$. If only influenced by the weathering of carbonate and silicate minerals, the ratio of DIC to TA would remain close to unity (Cai et al., 2004). However, $\mathrm{CO}_{2}$ production from soil organic matter respiration and imbalances between production and respiration along the aquatic continuum can increase DIC-to-TA ratios (Mayorga et al., 2005). Presumably, during the wet season and high discharge periods, more $\mathrm{CO}_{2}$ from soil organic matter respiration stored in the drainage basin is brought along the river system while less $\mathrm{CO}_{2}$ is lost to the atmosphere due to a faster transport and lower surface area to volume ratio (i.e., deeper water depths) (Bass et al., 2014). We suggest that changes in the DIC-to-TA ratio at the freshwater end-member may reflect inputs of soil organic matter respiration due to seasonal variations in discharge, temperature, and moisture content, and less $\mathrm{CO}_{2}$ degassing due to fast transport of water to the estuary. As the ratio of DIC to TA determines aquatic $\mathrm{pH}$ and the buffer capacity (Egleston et al., 2010), our observations indicate that variation of this ratio should be considered in future global carbon cycle models, in particular regarding how wet and drought cycles in future climate scenarios would affect coastal water acidification and how coastal waters will respond to a changing terrestrial carbon export (Regnier et al., 2013; Bauer et al., 2013). 

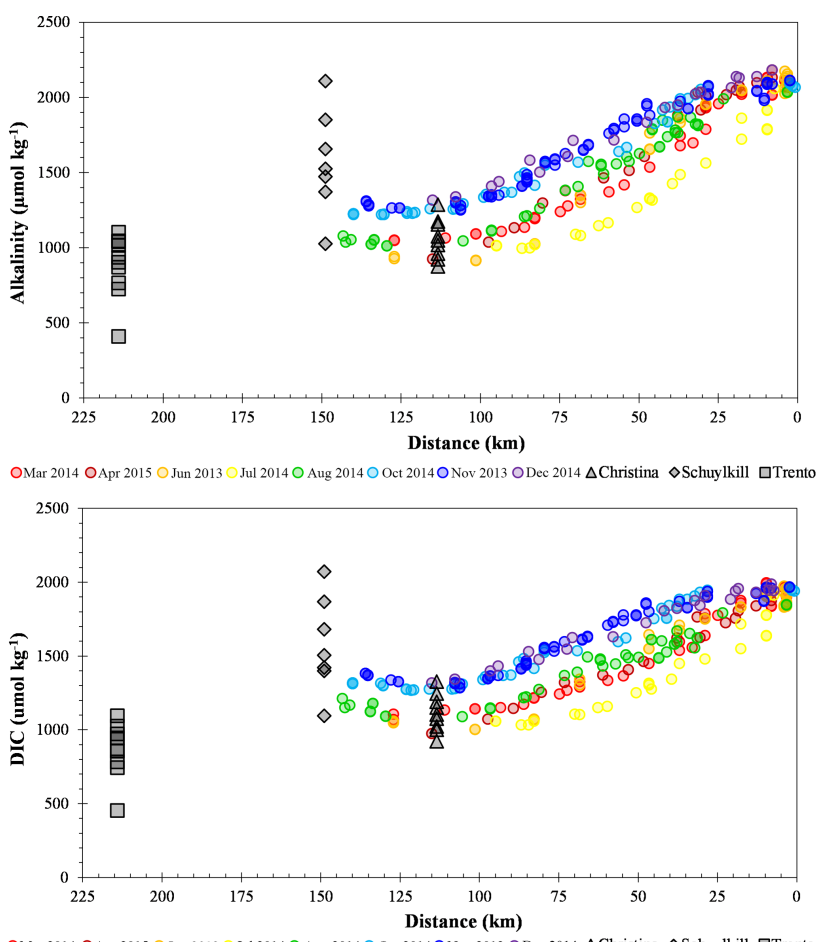

OMar 2014 OApr 2015 ○ Jun 2013 Jul 2014 ○ Aug 2014 ○ Oct 2014 O Nov 2013 ODec $2014 \Delta$ Christina $\diamond$ Schuylkill $\square$ Trenton

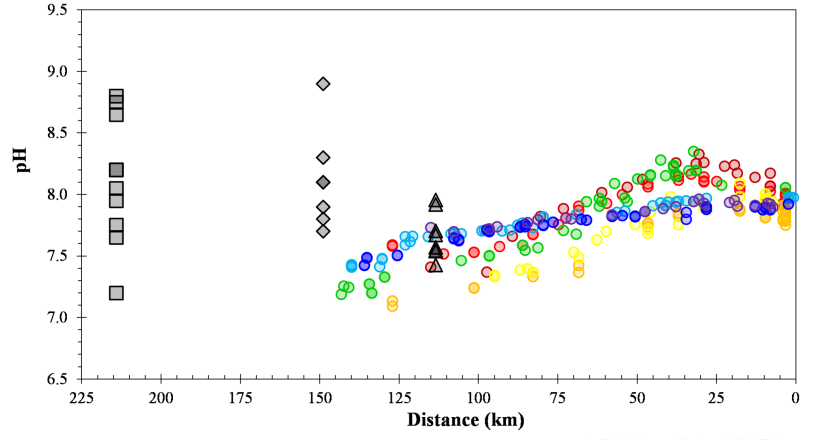

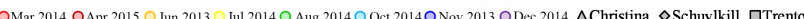

Figure 5. Spatial distribution of alkalinity, DIC, and $\mathrm{pH}$ in the Delaware Estuary from the mouth of the bay $(0 \mathrm{~km})$ to the head of the tide at Trenton, NJ $(215 \mathrm{~km})$.

\subsection{Influence of tributary mixing}

TA in the Schuylkill River was much higher than TA in the Delaware River near Philadelphia (Fig. 5). A compilation of historical data collected at two USGS stations in Philadelphia from 1940 to the present show that not only was alkalinity in the Schuylkill River negatively correlated with river discharge, but that during periods of low river discharge markedly high alkalinity was observed (Fig. 7a). Further, historical records agreed remarkably well with our alkalinity measurements. Over recent decades, after low river discharge $\left(<100 \mathrm{~m}^{3} \mathrm{~s}^{-1}\right)$ alkalinity reached from 1300 to $2500 \mu \mathrm{mol} \mathrm{kg}{ }^{-1}$, nearly 2 times greater than alkalinity values observed the Delaware River end-member (Fig. 7b).
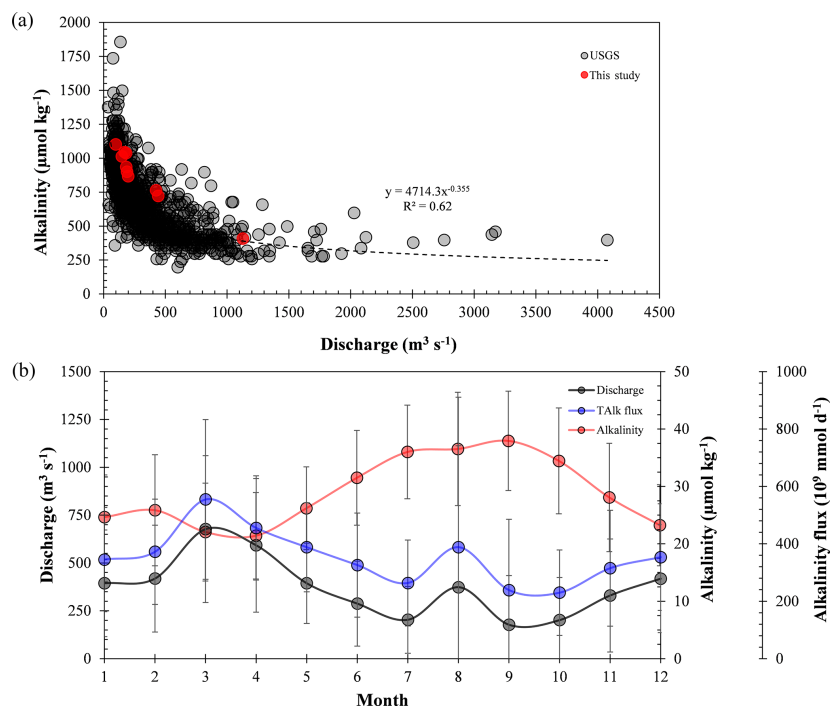

Figure 6. Relationship between alkalinity and Delaware River discharge at Trenton (1940-2015) (a). Black circles indicate data obtained from the USGS station while red circles indicate data collected in this study. Seasonal river discharge versus alkalinity and alkalinity flux for the same time period (b). Errors bars represent 1 standard deviation of the mean value for each month.
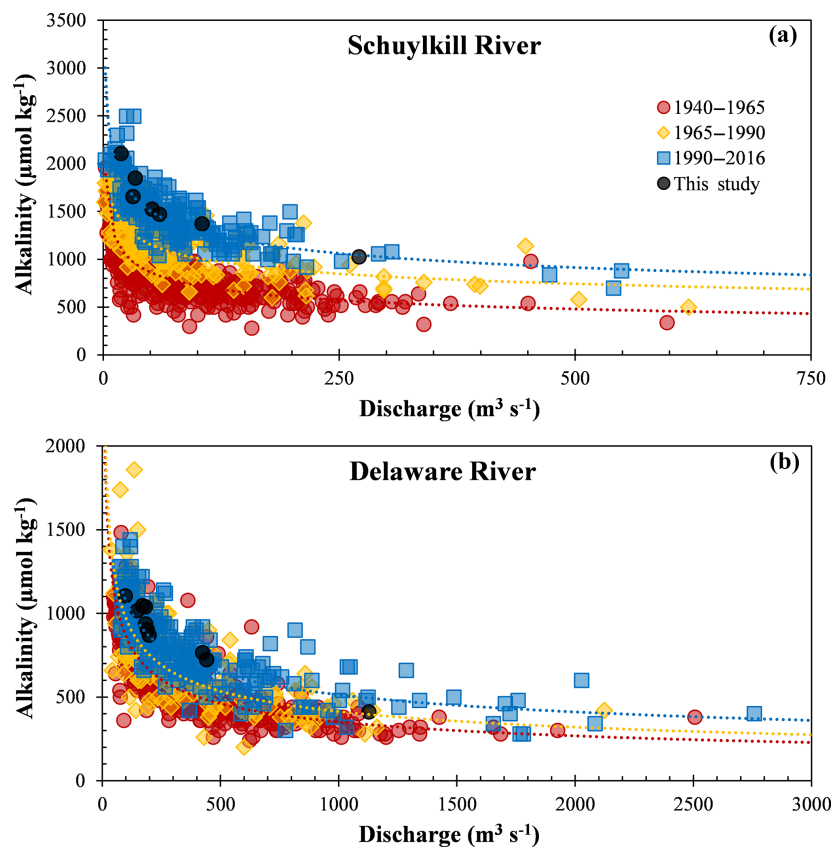

Figure 7. (a) Time series of the Schuylkill River discharge at Philadelphia, PA, and (b) the Delaware River discharge at Trenton, NJ, against alkalinity from 1940 to 2016 . Note the different scales used for each river.

The mineralogy of the Schuylkill River drainage basin may have a significant effect on TA patterns throughout the Delaware estuarine system. Geographically, the lower Schuylkill drainage basin extends through the Piedmont 
province, underlain by a mixture of limestone, shale, gneiss, schist, and dolomite, before discharging into the Coastal Plain province and the Delaware River (Stamer et al., 1985). Within this region, the Schuylkill River flows through the Valley Creek basin in which $68 \%$ of the region is comprised of carbonate rocks (Sloto, 1990). The center of the basin, otherwise known as Chester Valley, is primarily underlain by easily eroded limestone and dolomite bedrock with regional flow discharging into the Schuylkill River. Thus, it is likely that high riverine TA in the Schuylkill River is due to the weathering of carbonate rocks in the lower Schuylkill drainage basin. We contend that elevated DIC and TA values exhibited in the Delaware River near Philadelphia are the result of the mixing of relatively high carbonate freshwater from the Schuylkill River, specifically due to the chemical weathering of limestone and dolomite bedrock across the lower Piedmont province. It stands to reason that tributary contributions must be considered when addressing total riverine DIC and TA fluxes as differences in drainage basin mineralogy can have a substantial effect on the carbonate chemistry throughout regional watersheds.

\subsection{Historical trends in riverine alkalinity}

Over the past century, changes in land-use activity have significantly impacted the watershed export of organic and inorganic carbon, acids, and nutrients to the coastal ocean (Duarte et al., 2013). Long-term USGS records of river alkalinity in the Schuylkill River show that not only are alkalinity and river discharge negatively correlated, but that over decadal periods alkalinity values have increased with time (Fig. 7a). Although changes were not as great, a similar increasing trend in river alkalinity was also observed in the historical USGS dataset for the Delaware River (Fig. 7b). A more comprehensive study by Kaushal et al. (2013) found that alkalinity increased in 62 of 97 rivers in the eastern US over decadal timescales. Alkalinity did not significantly change at the remaining sites. Various factors can influence long-term trends in river alkalinity such as carbonate lithology, acid deposition, and topography in watersheds. Kaushal et al. (2013) suggested that increased acid deposition elevates riverine alkalinity by promoting weathering processes, particularly in watersheds with high carbonate lithology. Further, watershed elevation may be a good predictor for alkalization rates. Acid deposition may be greater at higher elevations, and such areas tend to have thinner soils and a weaker buffering capacity, increasing susceptibility to the effects of acid deposition. Recent studies show that humaninduced land-use changes such as deforestation, agricultural practices, and mining activities have direct impacts on the buffering capacity of streams and rivers (Brake et al., 2001; Oh and Raymond, 2006; Raymond and Oh, 2009). Through chemical weathering processes, enhanced precipitation and local runoff can also have huge effects on increased alkalinity in coastal ecosystems (Raymond et al., 2008). For ex- ample, it was suggested that over the past century, total alkalinity export from the Mississippi River to the Gulf of Mexico has risen by nearly $50 \%$ due to widespread cropland expansion and increased precipitation in the watershed (Raymond and Cole, 2003; Raymond et al., 2008). Similarly, Stets et al. (2014) explored historical time series of alkalinity values in 23 different riverine systems throughout the US. They found that alkalinity increased at 14 of these locations, mostly in the northeast, Midwest, and Great Plains of the US. While alkalinity increased over time at most locations, it decreased in the Santa Ana, upper Colorado, and Brazos rivers. Factors contributing to decreasing alkalinity at these locations include dilution by water from external sources outside the basin and retention of weathering products in storage reservoirs.

While numerous studies indicate increasing alkalinity in estuarine waters, the impact of methodological changes over time cannot be neglected. Conveniently, USGS has published a series of manuals, both past and present, discussing the analytical procedures and methods followed during specialized work in water resource investigations (Wood, 1976; Fishman and Friedman, 1989; Radtke et al., 1998). Historically, the USGS measured alkalinity as fixed endpoint titrations on unfiltered samples and commonly reported values as concentrations of bicarbonate (Clarke, 1924). By 1984, the USGS also began conducting fixed endpoint and incremental titrations on filtered samples (Raymond and Oh, 2009; Kaushal et al., 2013). Presently, USGS performs several variations of tests that describe the alkalinity, including standard alkalinity, acid neutralizing capacity, and carbonate alkalinity. Samples are measured using either a standard buret, micrometer buret, or an automated digital titrator (Fishman and Friedman, 1989; Radtke et al., 1998). Micrometer burets offer higher accuracy and precision than standard burets while automated titrators are more preferred due to convenience and durability (Radtke et al., 1998). Fixed endpoint titrations are generally less accurate than inflection-point titrations, especially in low carbonate waters or areas with high organic and noncarbonated contributions to alkalinity (Radtke et al., 1998). Such methodological changes, however, would result in an underestimate of alkalinity if at all (Kaushal et al., 2013). Thus, our conclusion of an increasing alkalinity trend in the Delaware River water would still hold and is a conservative estimate. Such an alkalinity increase has been observed in many river and estuarine systems (Raymond and Cole, 2003; Raymond and Oh, 2009; Duarte et al., 2013; Kaushal et al., 2013; Stets et al., 2014).

\subsection{Seasonal variation in estuarine DIC}

DIC in the Delaware Estuary also shifted with the seasons. In spring (March 2014 and April 2015) and summer (August 2014), DIC deviated slightly from conservative mixing in midsalinity waters ( $S \sim 15$ to 25 ) while TA varied linearly with salinity, suggesting consumption of $\mathrm{CO}_{2}$ in the water 


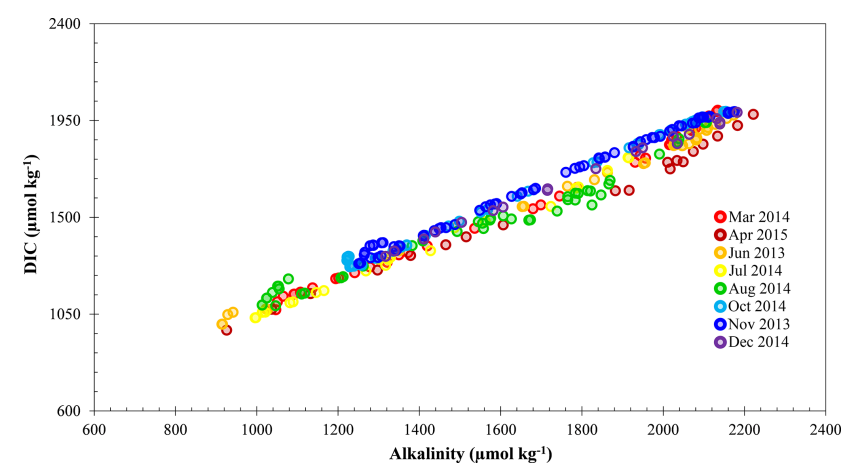

Figure 8. DIC versus alkalinity measured along the axis of the Delaware Estuary.

column (Fig. 3). During the same time, $\mathrm{pH}$ was highest over the entire year, consistent with the presence of a phytoplankton bloom in spring and late summer (Fig. 3). Nonlinear distributions were observed when plotting DIC against TA (Fig. 8). The curvature (concave upward trend at both ends) pattern indicates DIC removal in the mid-Delaware Bay during productive seasons. Joesoef et al. (2015) found that internal biological processes have a significant effect on $\mathrm{CO}_{2}$ dynamics within the Delaware Bay. In March and August 2014, $p \mathrm{CO}_{2}$ was low (160-350 $\left.\mu \mathrm{atm}\right)$ and $\mathrm{CO}_{2}$ uptake from the atmosphere was greatest $\left(-21-2.5 \mathrm{mmol} \mathrm{m}^{-2} \mathrm{~d}^{-1}\right)$ throughout the mid- and lower bay regions, indicating biological $\mathrm{CO}_{2}$ removal (Joesoef et al., 2015). Thus, while not as large as changes in weathering and precipitation rates on DIC variability, internal biological processes within the bay system can lead to seasonal shifts in DIC concentrations.

Strong linear trends of TA with salinity across the estuarine mixing zone throughout all seasons suggest that the export of inorganic carbon from salt marshes to the main channel of the estuary is relatively small. If this was not the case, TA and DIC to salinity relationships would show a midpoint enrichment above the mixing line, as $\mathrm{SO}_{4}^{2-}$ reduction is an important organic matter decomposition pathway that would generate $\mathrm{HCO}_{3}^{-}$in salt marshes (Cai and Wang, 1998; Jiang et al., 2008). Such humpback enrichment is not observed here. Nonetheless, it is evident that more research in estuarine systems is needed to accurately depict the influence of salt marsh exports on the carbonate chemistry of estuarine waters, especially in larger bay systems with long freshwater residence times.

\subsection{DIC mass balance}

Using freshwater discharge from the Delaware, Schuylkill, and Christina rivers (Table 1), DIC input fluxes to the estuary were computed for each cruise based on the linear relationships shown in Fig. 4. Combining total DIC fluxes for each river, we obtain an annual-averaged DIC input flux of $11.0 \pm 5.8 \times 10^{9} \mathrm{molCyr}^{-1}$. Using the effec- tive concentrations extrapolated from the high-salinity water, an annual-averaged DIC export flux to the ocean of $11.5 \pm 7.4 \times 10^{9} \mathrm{molC} \mathrm{yr}^{-1}$ was calculated. Since approximately $70 \%$ of the freshwater input to the estuary comes from the Delaware, Schuylkill, and Christina rivers, and the remaining input comes from small rivers, nonpoint source runoff, and waste water treatment facilities, we estimate that the Delaware, Schuylkill, and Christina rivers provide the estuary with about $70 \%$ of its total freshwater input, calculated from the combined annual mean discharge $\left(387 \mathrm{~m}^{3} \mathrm{~s}^{-1}\right)$ of these rivers during 2013-2015. By scaling upward, we obtain an annual mean discharge of $553 \mathrm{~m}^{3} \mathrm{~s}^{-1}$ and a final DIC input flux of $15.7 \pm 8.2 \times 10^{9} \mathrm{molCyr}^{-1}$ and export flux of $16.5 \pm 10.6 \times 10^{9} \mathrm{molC} \mathrm{yr}^{-1}$. We acknowledge that average riverine DIC and TA concentrations from remaining small rivers and nonpoint source runoff are not necessarily equivalent to the weighted DIC and TA averages for the Delaware, Schuylkill, and Christina rivers. As such uncertainties are most often neglected, it is necessary to consider their effect on final flux estimates. However, in the absence of pertinent data, here we assume that the mineralogy and drainage basins of the remaining $30 \%$ yield similar carbonate concentrations as the estuary's three major river systems. In this study, we upscaled both the river-to-estuary flux and the estuaryto-offshore flux by the same proportion $(10 / 7)$ to estimate the total estuarine input and export fluxes. Thus, the uncertainty derived from upscaling would be partially canceled out and would not substantially affect the conclusions discussed below. Annual air-water $\mathrm{CO}_{2}$ flux to the atmosphere from the Delaware Estuary has recently been estimated as $2.4 \pm 4.8 \mathrm{~mol} \mathrm{C} \mathrm{m}^{-2} \mathrm{yr}^{-1}$ (Joesoef et al., 2015). Using the annual air-water $\mathrm{CO}_{2}$ flux and an estimated surface water area of $1773 \mathrm{~km}^{2}$ for the estuarine system (Sutton et al., 1996), the total $\mathrm{CO}_{2}$ flux to the air is estimated as $4.3 \times 10^{9} \mathrm{molC} \mathrm{yr}^{-1}$. Thus, a DIC mass balance for the estuary is as follows.

$$
\begin{aligned}
& \text { River input flux }\left(15.7 \times 10^{9} \mathrm{molC} \mathrm{yr}^{-1}\right) \\
& \quad+\text { Internal estuarine } \mathrm{CO}_{2} \text { production (?) } \\
& \quad+\text { Inputs from surrounding salt marshes (?) } \\
& \quad+\text { Inputs from benthic recycling (?) } \\
& \quad=\text { Estuarine output flux }\left(16.5 \times 10^{9} \mathrm{molC} \mathrm{yr}^{-1}\right) \\
& + \text { Atmospheric flux }\left(4.3 \times 10^{9} \mathrm{molC} \mathrm{yr}^{-1}\right)
\end{aligned}
$$

The sum of the unknown internal DIC production terms is estimated at $5.1 \times 10^{9} \mathrm{molC} \mathrm{yr}^{-1}$. This internal DIC production includes respiration in the water column and benthos, $\mathrm{CO}_{2}$ addition from intertidal marsh waters, wastewater effluents, groundwater discharge, and other various external sources. If we pool water column and benthic respiration into one term and ignore additional input from wastewater effluents and groundwater discharge, DIC fluxes can be viewed as a measure of net ecosystem production (NEP). Using DIC input and export fluxes and air-water $\mathrm{CO}_{2}$ fluxes from Joesoef et al. (2015), we estimate NEP dur- 

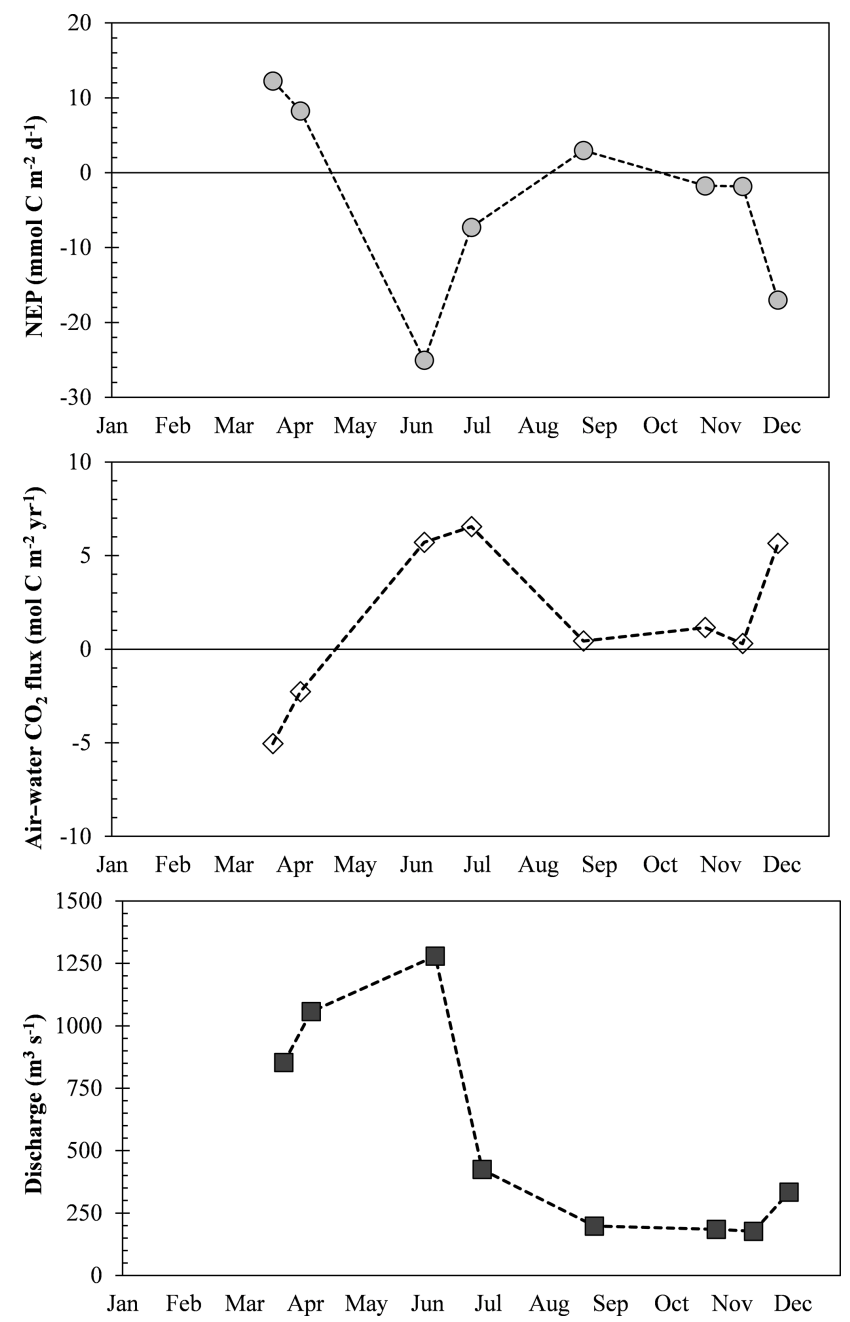

Figure 9. Seasonal variations of net ecosystem production, airwater $\mathrm{CO}_{2}$ fluxes, and discharge in the Delaware Estuary. Note the different scales used for each plot. Discharge is defined as the average of the total discharge to the estuary recorded during each cruise period including discharges recorded 10 days prior to the survey.

ing each cruise as described above (Fig. 9). In early spring, positive NEP indicates that the estuary is net autotrophic $\left(10.3 \pm 2.0 \mathrm{mmolC} \mathrm{m}^{-2} \mathrm{~d}^{-1}\right)$, and exports or stores an excess of organic carbon. A shift to negative NEP in the summer $\left(-9.8 \pm 11.6 \mathrm{mmol} \mathrm{C} \mathrm{m}^{-2} \mathrm{~d}^{-1}\right)$ indicates a net heterotrophic system where ecosystem metabolism is sustained by external inputs of organic matter (Fig. 9). In contrast, from fall to early winter season, the estuary fluctuates from a nearly balanced ecosystem to a net heterotrophic environment.

Other studies have explored NEP across the estuarine gradient of the Delaware Estuary (Sharp et al., 1982; Lipschultz et al., 1986; Hoch and Kirchman, 1993; Preen and Kirchman, 2004). Significant depletion of dissolved oxygen and supersaturation of $p \mathrm{CO}_{2}$ levels in freshwaters (salinity $<10$ ), suggests that the upper estuary is heterotrophic while the lower estuary is autotrophic (Sharp et al., 1982). More recent stud- ies have found that respiration often exceeds primary production in the upper Delaware River (Hoch and Kirchman, 1993; Preen and Kirchman, 2004). Comparably, Culberson (1988) used inorganic carbon and dissolved oxygen measurements to estimate apparent carbon production and oxygen utilization throughout the Delaware Estuary. Similar to our spring NEP results, Culberson (1988) found that during the months of March to May from 1978 to 1985, most of the estuary $(6<S<30)$ suffered a net inorganic carbon loss. Presumably, this loss occurred during the spring phytoplankton bloom, a period of intense inorganic carbon uptake by phytoplankton. While respiration rates often outweigh primary production in the upper tidal river, generally net community production increases down the estuary, transitioning to a nearly balanced and autotrophic system in the mid- to lower bay regions (Hoch and Kirchman, 1993; Preen and Kirchman, 2004).

Despite high $\mathrm{CO}_{2}$ consumption during the spring and late summer, annually the Delaware Estuary is a weak source of DIC with an NEP $=-1.3 \pm 3.8 \mathrm{molCm}^{-2} \mathrm{yr}^{-1}$, which is in sharp contrast to many smaller river estuaries that exhibit strong net heterotrophy $\left(-17 \pm 23 \mathrm{~mol} \mathrm{C} \mathrm{m}^{-2} \mathrm{yr}^{-1}\right.$ ) (Borges and Abril, 2011). Of the 79 estuarine studies compiled by Borges and Abril (2011) that reported gross primary production (GPP), community respiration (CR), and NEP rates, overall only 12 estuaries are net autotrophic. Most estuaries are strongly net heterotrophic, probably because of high inputs of labile organic matter from tributaries that support CR while GPP is reduced due to limited light availability caused by elevated suspended matter (Smith and Hollibaugh, 1993; Heip et al., 1995; Gattuso et al., 1998; Gazeau et al., 2004; Borges and Abril, 2011). However, the relationship between NEP and GPP varies considerably across different estuaries depending on factors such as the degree of light limitation, the fraction of inorganic nutrient to organic carbon inputs, and the size of the estuarine system, with smaller estuaries showing increased heterotrophy over larger systems such as the Delaware Bay (Hopkinson, 1988; Heip et al., 1995; Kemp et al., 1997; Caffrey, 2004; Borges and Abril, 2011).

Riverine input and estuarine export fluxes varied greatly over time and are largely governed by seasonal discharge patterns (Tables 2 and 3). The highest fluxes occurred during spring when discharge was high while the lowest values occurred in the fall and winter when discharge was low. However, seasonal changes in NEP did not reflect variations in river discharge. Discharge decreased throughout the year while NEP rates fluctuated across seasons (Fig. 9). Instead, NEP largely mirrored seasonal variations in air-water $\mathrm{CO}_{2}$ fluxes. When the estuary acted as a source of $\mathrm{CO}_{2}$, NEP was negative while when the system was a $\mathrm{CO}_{2}$ sink, NEP was positive. From the annual mass balance model, the small difference between riverine input and export flux suggests that the majority of DIC produced within the estuary is exchanged with the atmosphere rather than exported to the 
ocean. More research and data are needed to accurately ascertain seasonal variations in estuarine fluxes and NEP.

Unlike in most previously studied estuaries, but similar to the macrotidal Scheldt Estuary, freshwater residence time in the Delaware Bay is generally long, from about one to a few months (Gay and O'Donnell, 2009; Borges and Abril, 2011). In contrast, the smaller stratified Randers Fjord has a much shorter residence time (a few days) (Nielsen et al., 2001). In the smaller Randers Fjord, $\mathrm{CO}_{2}$ emission to the atmosphere is lower than net community production (NCP) in the mixed layer or much less significant (Gazeau et al., 2005). This occurrence is partly due to the decoupling in ecosystem production caused by water stratification. As organic matter is produced in the surface waters, its degradation occurs in the bottom waters, ultimately delaying $\mathrm{CO}_{2}$ exchange with the atmosphere (Borges and Abril, 2011). Further, total DIC export to the Baltic Sea is higher than riverine DIC inputs to the Randers Fjord, suggesting that, due to the shorter freshwater residence times, much of the DIC produced by net respiration is exported rather than removed to the atmosphere (Gazeau et al., 2005). Comparably, the Rhine exhibits extremely short freshwater residence time ( $\sim 2$ days) due to intense freshwater discharge $\left(\sim 2200 \mathrm{~m}^{3} \mathrm{~s}^{-1}\right)$. Such rapid turnover time leads to reduced emission of methane $\left(\mathrm{CH}_{4}\right)$ to the atmosphere and smaller internal DIC production due to net heterotrophy (Borges and Abril, 2011). A similar case study was seen for the rapidly transiting Altamaha River in the US southeastern coast (Cai and Wang, 1998; Jiang et al., 2008). However, lateral inputs from intertidal marsh systems in small estuaries can enhance accumulation and degradation of organic matter in surface waters, resulting in high $\mathrm{CO}_{2}$ degassing fluxes (Dai and Wiegert, 1996; Cai and Wang, 1998; Neubauer and Anderson, 2003).

Due to the large size of the Delaware Bay, the effect from the production and decomposition of marsh plants on $\mathrm{CO}_{2}$ flux dynamics in the system may not be as influential as in smaller estuaries, except near the coastlines where tides regularly flush marsh boundaries (Joesoef et al., 2015). In this study, we did not sample the subestuaries within or the areas near the perimeters of the bay, but instead were limited to sampling within the main channel of the estuary. We note while the Delaware River is only a medium-sized river, the Delaware Bay is one of the largest bays on the US eastern coast and its hydrodynamics are largely controlled by the exchange with the ocean. In the Scheldt Estuary, a long freshwater residence time typically leads to DIC accumulation in the water column (Abril et al., 2000; Borges et al., 2006). In addition, in both the Delaware and Scheldt estuaries, small differences between riverine input and export flux suggest that the majority of DIC produced within the estuary is exchanged with the atmosphere rather than exported to the ocean. While similar NEP values may be observed, the enrichment of DIC in estuarine waters and resulting $\mathrm{CO}_{2}$ exchange with the atmosphere will be more intense in estuarine systems with long residence times versus estuaries with short residence times (Borges and Abril, 2011). Thus, we suspect that in estuaries with long freshwater residence times (e.g., the Delaware Estuary), much of the DIC produced by NEP is most likely removed to the atmosphere rather than exported to the sea.

\section{Conclusion}

Strong negative correlations between river TA and freshwater discharge in the nontidal Delaware, Schuylkill, and Christina rivers suggest that changes in $\mathrm{HCO}_{3}^{-}$concentrations in the Delaware Estuary reflect dilution of weathering products in the drainage basin. Elevated DIC and TA concentrations near the Philadelphia region in the upper estuary are largely the result of relatively high carbonate freshwater from the lower Schuylkill River drainage basin, a consequence of chemical weathering of limestone and dolomite bedrock. Increased alkalinity in the Delaware and Schuylkill rivers over the past 70 years coincide with global trends toward higher alkalinity in river and estuarine waters over decadal timescales. In addition to strong variations in discharge and mixing from the three rivers, seasonal changes in NEP within the estuary also contribute to shifts in DIC concentrations. Lastly, a preliminary mass balance analysis indicates only a small difference between riverine DIC input and export flux, suggesting that, in the Delaware Estuary and other estuarine systems with long freshwater residence times, much of the DIC produced by NEP or supplied from surrounding marshes is most likely emitted to the atmosphere rather than exported to the sea.

Data availability. Data are available at the NOAA National Centers for Environmental Information (NCEI) https://www.nodc.noaa.gov/ with Reference ID: 3G9X4J. Data are also available from the corresponding author by email request.

Competing interests. The authors declare that they have no conflict of interest.

Acknowledgements. Wei-Jun Cai acknowledges UD internal funds and the National Aeronautics and Space Administration (NNX14AM37G) for supporting his research. David L. Kirchman was supported by NSF OCE-1030306 and OCE-1261359. The cruises were supported by awards from the National Science Foundation (OCE-1155385, OCE-1261359, and OCE-1030306) and the Delaware Sea Grant College Program (RHCE14-DESG). In addition, we would like to thank the captains and crew of the R/V Hugh R. Sharp and the R/V Joanne Daiber for their tremendous support. We also thank Jonathan H. Sharp, George W. Luther III, Jonathan H. Cohen, and Barbara J. Campbell for providing us with the opportunity to participate on their research cruises. 
Edited by: Jack Middelburg

Reviewed by: three anonymous referees

\section{References}

Abril, G., Etcheber, H., Borges, A. V., and Frankignoulle, M.: Excess atmospheric carbon dioxide transported by rivers into the Scheldt estuary, Cr. Acad. Sci. II A., 330, 761-768, 2000.

Abril, G., Martinez, J.-M., Artigas, L. F., Moreira-Turcq, P., Benedetti, M. F., Vidal, L., Meziane, T., Kim, J.-H., Bernardes, M. C., Savoye, N., Deborde, J., Albéric, P., Souza, M. F. L., Souza, E. L., and Roland, F.: Amazon River carbon dioxide outgassing fueled by wetlands, Nature, 505, 395-398, 2014.

Aristizábal, M. F. and Chant, R. J.: An observational study of salt fluxes in Delaware Bay, J. Geophys. Res-Oceans., 120, 27512768, 2015.

Aumont, O., Orr, J. C., Monfray, P., Ludwig, W., Amiotte-Suchet, P., and Probst, J. L.: Riverine-driven interhemispheric transport of carbon, Global Biogeochem. Cy., 15, 393-405, 2001.

Bass, A. M., Munksgaard, N. C., Leblanc, M., Tweed, S., and Bird, M. I.: Contrasting carbon export dynamics of human impacted and pristine tropical catchments in response to a short-lived discharge event, Hydrol. Process., 28, 1835-1843, 2014.

Bastviken, D., Tranvik, L. J., Downing, J. A., Crill, P. M., and Enrich-Prast, A.: Freshwater methane emissions offset the continental carbon sink, Science, 331, 50, 2011.

Battin, T. J., Luyssaert, S., Kaplan, L. A., Aufdenkampe, A. K., Richter, A., and Tranvik, L. J.: The boundless carbon cycle, Nat. Geosci., 2, 598-600, 2009.

Bauer, J. E., Cai, W.-J., Raymond, P. A., Bianchi, T. S., Hopkinson, C. S., and Regnier, P. A.: The changing carbon cycle of the coastal ocean, Nature, 504, 61-70, 2013.

Borges, A. V. and Abril, G.: Carbon dioxide and methane dynamics in estuaries, in: Treatise on estuarine and coastal science, edited by: Wolanski, E. and McLusky, D., Academic Press, Waltham, 119-161, 2011.

Borges, A. V., Schiettecatte, L.-S., Abril, G., Delille, B., and Gazeau, F.: Carbon dioxide in European coastal waters, Estuar. Coast. Shelf. S., 70, 375-387, 2006.

Boyle, E., Collier, R., Dengler, A. T., Edmond, J. M., Ng, A. C., and Stallard, R. F.: On the chemical mass-balance in estuaries, Geochim. Cosmochim. Ac., 38, 1719-1728, 1974.

Brake, S., Connors, K., and Romberger, S.: A river runs through it: impact of acid mine drainage on the geochemistry of West Little Sugar Creek pre- and post-reclamation at the Green Valley coal mine, Indiana, USA, Environ. Geol., 40, 1471-1481, 2001.

Caffrey, J. M.: Factors controlling net ecosystem metabolism in U.S. estuaries, Estuaries, 27, 90-101, 2004.

Cai, W.-J.: Riverine inorganic carbon flux and rate of biological uptake in the Mississippi River plume, Geophys. Res. Lett., 30, 1032, https://doi.org/10.1029/2002GL016312, 2003.

Cai, W.-J.: Estuarine and coastal ocean carbon paradox: $\mathrm{CO}_{2}$ sinks or sites of terrestrial carbon incineration?, Annu. Rev. Mar. Sci., 3, 123-145, 2011.

Cai, W.-J. and Wang, Y.: The chemistry, fluxes, and sources of carbon dioxide in the estuarine waters of the Satilla and Altamaha Rivers, Georgia, Limnol. Oceanogr., 43, 657-668, 1998.
Cai, W.-J., Wang, Y., Krest, J., and Moore, W. S.: The geochemistry of dissolved inorganic carbon in a surficial groundwater aquifer in North Inlet, South Carolina, and the carbon fluxes to the coastal ocean, Geochim. Cosmochim. Ac., 67, 631-639, 2003.

Cai, W.-J., Dai, M., Wang, Y., Zhai, W., Huang, T., Chen, S., Zhang, F., Chen, Z., and Wang, Z.: The biogeochemistry of inorganic carbon and nutrients in the Pearl River estuary and the adjacent Northern South China Sea, Cont. Shelf Res., 24, 1301-1319, 2004.

Cai, W.-J., Guo, X., Chen, A., Dai, M., Zhang, L., Zhai, W., Lohrenz, S. E., Yin, K., Harrison, P. J., and Wang, Y.: A comparative overview of weathering intensity and $\mathrm{HCO}_{3}^{-}$flux in the world's major rivers with emphasis on the Changjiang, Huanghe, Zhujiang (Pearl) and Mississippi Rivers, Cont. Shelf. Res., 28, 1538-1549, https://doi.org/10.1016/j.csr.2007.10.014, 2008.

Cai, W.-J., Hu, X., Huang, W.-J., Jiang, L.-Q., Wang, Y., Peng, T.H., and Zhang, X.: Alkalinity distribution in the western North Atlantic Ocean margins, J. Geophys. Res.-Oceans., 115, 1-15, 2010.

Chen, C.-T. A. and Borges, A. V.: Reconciling opposing views on carbon cycling in the coastal ocean: Continental shelves as sinks and near-shore ecosystems as sources of atmospheric $\mathrm{CO}_{2}$, Deep-Sea. Res. Pt. II., 56, 578-590, 2009.

Chen, C.-T. A., Zhai, W., and Dai, M.: Riverine input and airsea $\mathrm{CO}_{2}$ exchanges near the Changjiang (Yangtze River) Estuary: Status quo and implication on possible future changes in metabolic status, Cont. Shelf Res., 28, 1476-1482, 2008.

Clarke, F. W.: The composition of the river and lake waters of the United States, U.S. Geological Survev Professional Paper, 135, 2-9, 1924.

Cooley, S. R., Coles, V. J., Subramaniam, A., and Yager, P. L.: Seasonal variations in the Amazon plume-related atmospheric carbon sink, Global Biogeochem. Cy., 21, GB3014, https://doi.org/10.1029/2006GB002831, 2007.

Cotrim da Cunha, L., Buitenhuis, E. T., Le Quéré, C., Giraud, X., and Ludwig, W.: Potential impact of changes in river nutrient supply on global ocean biogeochemistry, Global Biogeochem. Cy., 21, GB4007, https://doi.org/10.1029/2006GB002718, 2007.

Culberson, C. H.: Dissolved oxygen, inorganic carbon, and the acid-base system in the Delaware Estuary, in: Ecology and Restoration of the Delaware River Basin, Pennsylvania Academy of Science, University of Michigan, 58-76, 1988.

Dai, T. and Wiegert, R. G.: Estimation of the primary productivity of Spartina alterniflora using a canopy model, Ecography, 19, 410 423, 1996.

Downing, J. A., Cole, J. J., Middelburg, J. J., Striegl, R. G., Duarte, C. M., Kortelainen, P., Prairie, Y. T., and Laube, K. A.: Sediment organic carbon burial in agriculturally eutrophic impoundments over the last century, Global Biogeochem. Cy., 22, GB1018, https://doi.org/10.1029/2006GB002854, 2008.

Duarte, C. M., Hendriks, I. E., Moore, T. S., Olsen, Y. S., Steckbauer, A., Ramajo, L., Carstensen, J., Trotter, J. A., and McCulloch, M.: Is ocean acidification an open-ocean syndrome? Understanding anthropogenic impacts on seawater $\mathrm{pH}$, Estuar. Coast., 36, 221-236, 2013.

Dürr, H. H., Laruelle, G. G., van Kempen, C. M., Slomp, C. P., Meybeck, M., and Middelkoop, H.: World-wide typology of near- 
shore coastal systems: defining the estuarine filter of river inputs to the oceans, Estuar. Coast., 34, 441-458, 2011.

Egleston, E. S., Sabine, C. L., and Morel, F. M.: Revelle revisited: Buffer factors that quantify the response of ocean chemistry to changes in DIC and alkalinity, Global Biogeochem. Cy., 24, GB1002, https://doi.org/10.1029/2008GB003407, 2010.

Ferrón, S., Ortega, T., Gómez-Parra, A., and Forja, J. M.: Seasonal study of dissolved $\mathrm{CH}_{4}, \mathrm{CO}_{2}$ and $\mathrm{N}_{2} \mathrm{O}$ in a shallow tidal system of the bay of Cádiz (SW Spain), J. Marine Syst., 66, 244-257, 2007.

Fishman, M. J. and Friedman, L. C.: Methods for determination of inorganic substances in water and fluvial sediments, in: Techniques of Water-Resources Investigations of the United States Geological Survey, No. 05-A1, 1989.

Gattuso, J. P., Frankignoulle, M., and Wollast, R.: Carbon and carbonate metabolism in coastal aquatic ecosystems, Annu. Rev. Ecol. Syst., 29, 405-434, 1998.

Gay, P. and O'Donnell, J.: Comparison of the salinity structure of the Chesapeake Bay, the Delaware Bay and Long Island Sound using a linearly tapered advection-dispersion model, Estuar. Coast., 32, 68-87, 2009.

Gazeau, F., Smith, S. V., Gentili, B., Frankignoulle, M., and Gattuso, J. P.: The European coastal zone: characterization and first assessment of ecosystem metabolism, Estuar. Coast. Shelf S., 60, 673-694, 2004.

Gazeau, F., Borges, A. V., Barrón, C., Duarte, C. M., Iversen, N., Middelburg, J. J., Delille, B., Pizay, M. D., Frankignoulle, M., and Gattuso, J. P.: Net ecosystem metabolism in a micro-tidal estuary (Randers Fjord, Denmark): evaluation of methods, Mar. Ecol. Prog. Ser., 301, 23-41, 2005.

Gran, G.: Determination of the equivalent point in potentiometric titrations, Acta Chem. Scand., 4, 559-577, 1952.

Guo, X., Cai, W.-J., Zhai, W., Dai, M., Wang, Y., and Chen, B.: Seasonal variations in the inorganic carbon system in the Pearl River (Zhujiang) estuary, Cont. Shelf Res., 28, 1424-1434, 2008.

Heip, C. H. R., Goosen, N. K., Herman, P. M. J., Kromkamp, J. C., Middelburg, J. J., and Soetaert, K. E. R.: Production and consumption of biological particles in temperate tidal estuaries, Oceangr. Mar. Biol., 33, 1-149, 1995.

Hoch, M. P. and Kirchman, D. L.: Seasonal and inter-annual variability in bacterial production and biomass in a temperate estuary, Mar. Ecol. Prog. Ser., 98, 283-295, 1993.

Hopkinson, C. S.: Patterns of organic carbon exchange between coastal ecosystems: the mass balance approach in salt marsh ecosystems, in: Coastal-Offshore Ecosystems Interactions, Springer, Berlin, 122-154, 1988.

Huang, W.-J., Wang, Y., and Cai, W.-J.: Assessment of sample storage techniques for total alkalinity and dissolved inorganic carbon in seawater, Limnol. Oceanogr.-Meth., 10, 711-717, 2012.

Jiang, L.-Q., Cai, W.-J., and Wang, Y.: A comparative study of carbon dioxide degassing in river- and marine-dominated estuaries, Limnol. Oceanogr., 53, 2603-2615, 2008.

Joesoef, A., Huang, W.-J., Gao, Y., and Cai, W.-J.: Air-water fluxes and sources of carbon dioxide in the Delaware Estuary: spatial and seasonal variability, Biogeosciences, 12, 6085-6101, https://doi.org/10.5194/bg-12-6085-2015, 2015.

Karim, A. and Veizer, J.: Weathering processes in the Indus River Basin: implication from riverine carbon, sulfur, oxygen, and strontium isotopes, Chem. Geol., 170, 153-177, 2000.
Kaushal, S. S., Likens, G. E., Utz, R. M., Pace, M. L., Grese, M., and Yepsen, M.: Increased river alkalinization in the Eastern US, Environ. Sci. Technol., 47, 10302-10311, 2013.

Kemp, W. M., Smith, E. M., Marvin-DiPasquale, M., and Boynton, W. R.: Organic carbon-balance and net ecosystem metabolism in Chesapeake Bay, Mar. Ecol. Prog. Ser., 150, 229-248, 1997.

Lerman, A., Mackenzie, F. T., and Ver, L. M.: Coupling of the perturbed C-N-P cycles in industrial time, Aquat. Geochem., 10, 332, 2004.

Li, J. Y. and Zhang, J.: Variations of solid content and water chemistry at Nantong station and weathering processes of the Changjiang watershed, Resour. Environ. Yangtze Basin, 12, 363369, 2003.

Lipschultz, F., Wofsy, S. C., and Fox, L. E.: Nitrogen metabolism of the eutrophic Delaware River ecosystem, Limnol. Oceanogr. 31, 701-716, 1986.

Liu, Z., Zhang, L., Cai W.-J., Wang, L., Xue, M., and Zhang, X.: Removal of dissolved inorganic carbon in the Yellow River Estuary, Limnol. Oceanogr., 59, 413-426, 2014.

Mayorga, E., Aufdenkampe, A. K., Masiello, C. A., Krusche, A. V., Hedges, J. I., Quay, P. D., Richey, J. E., and Brown, T. A.: Young organic matter as a source of carbon dioxide outgassing from Amazonian rivers, Nature, 436, 538-541, 2005.

Neubauer, S. C. and Anderson, I. C.: Transport of dissolved inorganic carbon from a tidal freshwater marsh to the York River estuary, Limnol. Oceanogr., 48, 299-307, 2003.

Nielsen, K., Risgaard-Petersen, N., Sømod, B., Rysgaard, S., and Berg $\varnothing$, T.: Nitrogen and phosphorus retention estimated independently by flux measurements and dynamic modeling in the estuary, Randers Fjord, Denmark, Mar. Ecol. Prog. Ser., 219, 25-40, 2001.

Oh, N. H. and Raymond, P. A.: Contribution of agricultural liming to riverine bicarbonate export and $\mathrm{CO}_{2}$ sequestration in the Ohio River basin, Global Biogeochem. Cy., 20, GB3012, https://doi.org/10.1029/2005GB002565, 2006.

Preen, K. and Kirchman, D. L.: Microbial respiration and production in the Delaware Estuary, Aquat. Microb. Ecol., 37, 109-119, 2004.

Probst, J. L., NKounkou, R. R., Krempp, G., Bricquet, J. P., Thiébaux, J. P., and Olivry, J. C.: Dissolved major elements exported by the Congo and the Ubangi rivers during the period 1987-1989, J. Hydrol., 135, 237-257, 1992.

Quinton, J. N., Govers, G., Van Oost, K., and Bardgett, R. D.: The impact of agricultural soil erosion on biogeochemical cycling, Nat. Geosci., 3, 311-314, 2010.

Radtke, D. B., Wilde, F. D., Davis, J. V., and Popowski, T. J.: Alkalinity and acid neutralizing capacity, in Techniques of WaterResources Investigations of the United States Geological Survey, Book 9, Chap. A6, Sect. 6.6, 1998.

Raymond, P. A. and Cole, J. J.: Increase in the export of alkalinity from North America's largest river, Science, 301, 88-91, 2003.

Raymond, P. A. and Oh, N. H.: Long term changes of chemical weathering in rivers heavily impacted from acid mine drainage: insights on the impact of coal mining on regional and global carbon and sulfur budgets, Earth Planet. Sci. Lett., 284, 50-56, 2009.

Raymond, P. A., Oh, N. H., Turner, R. E., and Broussard, W.: Anthropogenically enhanced fluxes of water and carbon from the Mississippi River, Nature, 451, 449-452, 2008. 
Regnier, P., Friedlingstein, P., Ciais, P., Mackenzie, F. T., Gruber, N., Janssens, I. A., Laruelle, G. G., Lauerwald, R., Luyssaert, S., Andersson, A. J., Arndt, S., Arnosti, C., Borges, A. V., Dale, A. W., Gallego-Sala, A., Godderis, Y., Goossens, N., Hartmann, J., Heinze, C., Ilyina, T., Joos, F., LaRowe, D. E., Leifeld, J., Meysman, F. J. R., Munhoven, G., Raymond, P. A., Spahni, R., Suntharalingam, P., and Thullner, M.: Anthropogenic perturbation of the carbon fluxes from land to ocean, Nat. Geosci., 6, 597-607, https://doi.org/10.1038/ngeo1830, 2013.

Sharp, J. H., Culberson, C. H., and Church, T. M.: The chemistry of the Delaware estuary. General considerations, Limnol. Oceanogr., 27, 1015-1028, 1982.

Sharp, J. H., Yoshiyama, K., Parker, A. E., Schwartz, M. C., Curless, S. E., Beauregard, A. Y., Ossolinski, J. E., and Davis, A. R.: A biogeochemical view of estuarine eutrophication: seasonal and spatial trends and correlations in the Delaware Estuary, Estuar. Coast, 32, 1023-1043, 2009.

Sloto, R. A.: Geohydrology and simulation of ground-water flow in the carbonate rocks of the Valley Creek basin, eastern Chester County, Pennsylvania, U.S. Geological Survey Water-Resources Investigations Report, 89-4169, 1990.

Smith, S. V. and Hollibaugh, J. T.: Coastal Metabolism and the oceanic carbon balance, Rev. Geophys., 31, 75-89, 1993.

Sommerfield, C. K. and Wong, K. C.: Mechanisms of sediment flux and turbidity maintenance in the Delaware Estuary, J. Geophys. Res.-Oceans., 116, C01005, 2011.

Stamer, J. K., Yorke, T. H., and Pederson, G. L.: Distribution and transport of trace substances in the Schuylkill River Basin from Berne to Philadelphia, Pennsylvania, U.S. Geological Survey Water Supply Paper, 2256A, 1985.

Stets, E. G., Kelly, V. J., and Crawford, C. G.: Long-term trends in alkalinity in large rivers of the conterminous US in relation to acidification, agriculture, and hydrologic modification, Sci. Total Environ., 488, 280-289, 2014.
Sutton, C. C., O’Herron, J. C., and Zappalorti, R. T.: The Scientific Characterization of the Delaware Estuary, The Delaware Estuary Program, DRBC Project No. 321, HA File No. 93.21, 1996.

Ternon, J. F., Oudot, C., Dessier, A., and Diverres, D.: A seasonal tropical sink for atmospheric $\mathrm{CO}_{2}$ in the Atlantic Ocean: the role of the Amazon River discharge, Mar. Chem., 68, 183-201, 2000.

Tranvik, L. J., Downing, J. A., Cotner, J. B., Loiselle, S. A., Striegl, R. G., Ballatore, T. J., Dillon, P., Finlay, K., Fortino, K., Knoll, L. B., Kortelainen, P. L., Kutser, T., Larsen, S., Laurion, I., Leech, D. M., McCallister, S. L., McKnight, D. M., Melack, J. M., Overholt, E., Porter, J. A., Prairie, Y., Renwick, W. H., Roland, F., Sherman, B. S., Schindler, D. W., Sobek, S., Tremblay, A., Vanni, M. J., Verschoor, A. M., Wachenfeldt, E., and Weyhenmeyer, G. A.: Lakes and reservoirs as regulators of carbon cycling and climate, Limnol. Oceanogr., 54, 2298-2314, 2009.

Wang, Z. A. and Cai, W. J.: Carbon dioxide degassing and inorganic carbon export from a marsh-dominated estuary (the Duplin River): A marsh $\mathrm{CO}_{2}$ pump, Limnol. Oceanogr., 49, 341-354, 2004.

White, A. F.: Natural weathering rates of silicate minerals, in: Treatise on Geochemistry, edited by: Drever, J. I., Holland, H. D., and Turekian, K. K., Elsevier, Amsterdam, the Netherlands, 133$168,2003$.

White, A. F. and Blum, A. E.: Effects of climate on chemical weathering in watersheds, Geochim. Cosmochim. Ac., 59, 1729-1747, 1995.

Wong, K. C. and Sommerfield, C. K.: The variability of currents and sea level in the upper Delaware estuary, J. Mar. Res., 67, 479-501, 2009.

Wood, W. W.: Guidelines for collection and field analysis of ground-water samples for selected unstable constituents, in: Techniques of Water-Resources Investigations of the United States Geological Survey, No. 01-D2, 1976. 